UNDERGRADUATE RESEARCH IN NATURAL AND CLINICAL SCIENCE AND TECHNOLOGY (URNCST) JOURNAL

Read more URNCST Journal articles and submit your own today at: https://www.urncst.com

\title{
The 2019 Canadian Undergraduate Computer Science Conference
}

Aislyn A. Laurent, BSc Student [1]*, Noah Campbell BSc Student [2], Pooya Moradian Zadeh $\mathrm{PhD}$ [2], Austin Formagin BSc Student [2], Bryce Hughson BSc Student [2], David Worley BSc Student [2], Josh Gehl BSc Student [2], Ryan Lebeau BSc Student [2]

[1] Department of Chemistry and Biochemistry, University of Windsor, Windsor, Ontario, Canada, N9B 3P4

[2] Department of Computer Science, University of Windsor, Windsor, Ontario, Canada, N9B $3 \mathrm{P} 4$

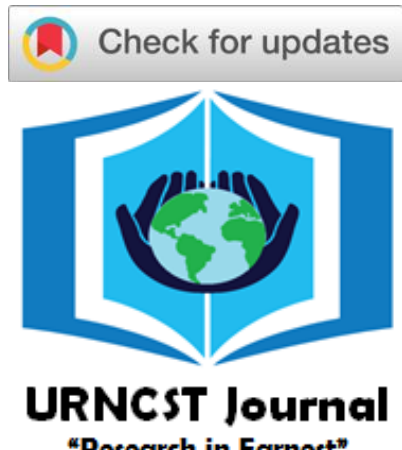

*Corresponding Author: lewisla@uwindsor.ca

\begin{abstract}
The Canadian Undergraduate Computer Science Conference (CUCSC) is an annual, national, and bilingual gathering of students in computer science and affiliated multidisciplinary fields run by and for undergraduate students. Since 2015, CUCSC has traditionally brought together 150 of the brightest computer science students from across Canada to connect with leaders in academia and industry working at the cutting edge of technology. Centered around computer science research excellence by Canadian undergraduate students and their research teams, CUCSC provides a platform to undergraduate research relating to computer science or technology from any field. Beginning in 2019, CUCSC has offered for the first time the opportunity for all delegates to have their work published, in the interest of furthering our goal of student success.
\end{abstract}

Keywords: Canadian Undergraduate Computer Science Conference; CUCSC; student research; undergraduate research; undergraduate; research; publications

\section{Introduction}

Computer science plays a massive role in nearly every aspect of today's society. Everything we do is being pushed forward by new waves of technology. From the smart devices in our homes to the artificial intelligence slowly entering our hospitals, technology has shaped how we live and learn. It is almost hard to imagine what life was like before the convenience of the internet and mobile technology. This impact provides the motivation to keep pushing further and making new discoveries. That is what the Canadian Undergraduate Computer Science Conference is all about.

CUCSC is a bilingual, annual, and national conference centered around computer science and computer scienceadjacent research by Canadian undergraduate students and their research teams. The 2019 Canadian Undergraduate Computer Science Conference was a three-day event which took place from July 25-27, and was hosted for the first time at the University of Windsor in Windsor, Ontario. Students from any discipline were strongly encouraged to apply not only to share their current and past projects with fellow students from across the country, but also to see and experience the work presented by their peers. This garnered participation from all disciplines of academia and industry including computer science, business, nursing, biology, biochemistry, and more.

\section{History}

CUCSC was first hosted at the University of British Columbia at Okanagan in 2015 [1]. Started by Yasha Pushak and his colleges, the event was inspired by the Canadian Undergraduate Mathematics Conference (CUMC), which has been taking place each summer since 1994 [2]. Like CUMC, the vision for CUCSC was an event organized by students, for students [1].

This first conference introduced many traditions which continue to this day. The strong focus on showcasing the hard work of undergraduate students is one such example. CUCSC continues to successfully offer a platform to students who may not otherwise be given the opportunity to present. Another example of this is the Women in Technology panel, which aims to inspire young women to continue to bring diverse ideas and perspectives to the industry.

\section{Goals}

Historically, the main and most important goal of CUCSC is to provide undergraduate students the opportunity and motivation to succeed. This is achieved in part by offering complete freedom of choice to the organizing committee. Each new group of organizing students can build connections in both industry and academia and build their portfolio through their role in organizing. Additionally, 
UNDERGRADUATE RESEARCH IN NATURAL AND CLINICAL SCIENCE AND TECHNOLOGY (URNCST) JOURNAL Read more URNCST Journal articles and submit your own today at: https://www.urnest.com

attendees can connect with their peers from across the country, learn more about the research opportunities available to them, and connect with faculty and industry professionals during the event.

This year, CUCSC 2019 has also taken on two secondary goals - the first to provide students with a broader view of the industry and academic landscape in computer science than in previous years, and second to showcase southwestern Ontario as a viable place to find work in technology. Both of these goals were achieved by inviting a broader range of speakers and presenters, with particular attention to speakers from the region who could speak to their successes as part of the community. This allowed students the chance to hear more about the opportunities available to them in research and industry, as well as to see which jobs were being offered in the region.

\section{Research}

Areas of focus were wide and varied, covering the depth and breadth of technology and computer science. Submissions were not limited to any specific topic, however, and relevant work in any discipline or area was considered. Work could be submitted and presented in either French or English. Each submission was peer reviewed by distinguished members of the technical committee. Undergraduate students were not required to be the primary author to present but were expected to have contributed significantly to the work.

For the first time in its history, CUCSC has published all accepted submissions. This is directly inline with the conferences stated goals of expanding the conferences reach and encouraging student success. For students hoping to move into graduate school, this experience is invaluable, as it allows them to learn about the process of peer review. For more career focus students, it shows their ability to prepare and deliver a professional, succinct presentation on their work.

\section{Conclusions}

In conclusion, CUCSC 2019 has achieved its goals and successfully built upon the strong foundation laid down by conferences held in previous years. Students were offered the chance to learn new resume building skills, publish their work and connect with new colleagues, peers and friends. Each year the organizing committee strives to expand the reach of this national event. The 2019 committee is proud to say that they have achieved this beyond their most ambitions hope.

Each member of the 2019 committee is glad to offer their sincerest best wishes to the upcoming CUCSC 2020 team. With hard work, determination and good luck, CUCSC may rival the outstanding record of CUMC, and inspire countless generations of strong computer science undergraduates to come.

\section{List of Abbreviations}

CUCSC: Canadian Undergraduate Computer Science

Conference

CUMC: Canadian Undergraduate Math Conference

URNCST: Undergraduate Research in Natural and Clinical Science and Technology

\section{Conflicts of Interest}

The authors declare that they have no conflicts of interest.

\section{Ethics Approval and/or Participant Consent}

This is not a scientific study and therefore did not require any ethics committee approval.

\section{Authors' Contributions \\ NC: Conference Chair \\ AAL: Conference Vice Chair \\ PMZ: Advisory Committee Chair \\ AF: Organizing Committee Member \\ BH: Organizing Committee Member \\ DW: Conference Vice Chair \\ JG: Organizing Committee Member \\ RL: Organizing Committee Member}

\section{Acknowledgements}

Special thanks to all the volunteers who helped make CUCSC 2019 Possible: Ashley Newton, Andrea Bonato, Harshdip Singh Deogan, Ivy Wills, Joel Rorseth, Karik Grant, Nuha Aljammas, Oksana Necio, Chashmeet Singh, Ferruccio Sisti, Harsh Sutariya, Manan Jadhav, Meera Moradiya, Mihir Samant, Prachi Solanki, Tafa Lee Burd

\section{Funding}

Funding for CUCSC 2019 was provided by our generous sponsors: CS-Can Info, The University of Windsor, Quicken Loans, Green Shield Canada, The Faculty of Science at the University of Windsor, WASP Cybersecurity Labs, WEtech Alliance, The University of Windsor Alumni Association

\section{References}

[1] Barber School Students Organize First Annual Canadian Undergraduate Computer Science Conference. [Internet].

[2] Irving K. Barber School of Arts and Sciences. [cited 2019 Aug 14]. Available from: ikbsas.ok.ubc.ca/2015/07/20/barber-school-studentsorganize-first-annual-canadian-undergraduatecomputer-science-conference/

[3] CUMC 2019 - Kingston. [Internet]. About the CUMC. [cited 2019 Aug 14]. Available from: cumc.math.ca/2019/about 


\section{Article Information}

Managing Editor: Jeremy Y. Ng

This article was not peer-reviewed.

Article Dates: Received Aug 16 19; Published Aug 3019

\section{Citation}

Please cite this article as follows:

Laurent AA, Campbell N, Zadeh PM, Formagin A, Hughson B, Worley D, Gehl J, Lebeau R. The 2019 Canadian

Undergraduate Computer Science Conference. URNCST Journal. 2019 Aug 30: 3(7).

https://urncst.com/index.php/urncst/article/view/159

DOI Link: https://doi.org/10.26685/urncst.159

\section{Copyright}

(c) Aislyn A. Laurent, Noah Campbell, Pooya Moradian Zadeh, Austin Formagin, Bryce Hughson, David Worley, Josh Gehl, Ryan Lebeau. (2019). Published first in the Undergraduate Research in Natural and Clinical Science and Technology (URNCST) Journal. This is an open access article distributed under the terms of the Creative Commons Attribution License (https://creativecommons.org/licenses/by/4.0/), which permits unrestricted use, distribution, and reproduction in any medium, provided the original work, first published in the Undergraduate Research in Natural and Clinical Science and Technology (URNCST) Journal, is properly cited. The complete bibliographic information, a link to the original publication on http://www.urncst.com, as well as this copyright and license information must be included.
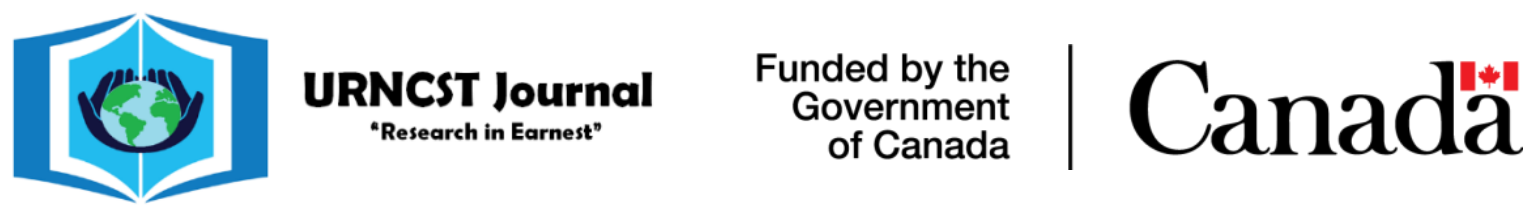

Do you research in earnest? Submit your next undergraduate research article to the URNCST Journal!

| Open Access | Peer-Reviewed | Rapid Turnaround Time | International | | Broad and Multidisciplinary | Indexed | Innovative | Social Media Promoted |

Pre-submission inquiries? Send us an email at info@urncst.com | Facebook, Twitter and LinkedIn: @URNCST

Submit YOUR manuscript today at https://www.urnest.com! 